\title{
Surgical treatment associated with adjuvant chemotherapy with cyclophosphamide and piroxicam in cervical sarcoma of a blue-fronted amazon (Amazona aestiva): case report
}

\author{
Tratamento cirúrgico com uso de quimioterapia adjuvante \\ com ciclofosfamida e piroxicam em sarcoma cervical de um \\ papagaio-verdadeiro (Amazona aestiva): relato de caso
}

\author{
Bruna Emely Pereira Barbosa ${ }^{1 *}(\mathbb{D})$, Felipe Noleto de Paiva² (1), \\ Marcel Ricardo Muzeti ${ }^{1}$ (D), Raissa Garib Pacheco do Amaral ${ }^{1}$ (D)
}

\begin{abstract}
The occurrence of neoplasms in birds is still unknown, with the literature based mainly on scarce reports, in this context, data about epidemiology in specific species are almost nonexistent. Sarcomas are malignant mesenchymal origin neoplasms, which can develop from different tissues, such as adipose, cartilage, bone, among others. The occurrence of sarcomas in birds has been previously described, with different therapeutic approaches. The present report describes the clinical approach in a blue-fronted amazon (Amazona aestiva) diagnosed with a soft tissue sarcoma in the dorsal cervical region, with surgical excision associated with a metronomic chemotherapy protocol as an adjuvant. The therapeutic combination proved to be effective in controlling the disease, guaranteeing important survival, with clinical absence of side effects.
\end{abstract}

KEYWORDS: oncology; neoplasm; histopathology; wild birds; parrots.

\begin{abstract}
RESUMO: A ocorrência das neoplasias em aves ainda é desconhecida, com a literatura se baseando principalmente em relatos escassos, nesse contexto, dados acerca de epidemiologia em espécies específicas são quase inexistentes. Os sarcomas são neoplasias malignas de origem mesenquimal, podendo se desenvolver a partir de tecidos diversos, como adiposo, cartilaginoso, ósseo, dentre outros. A ocorrência de sarcomas em aves já foi previamente descrita, com diferentes abordagens terapêuticas. O presente relato descreve a abordagem clínica em um papagaio-verdadeiro (Amazona aestiva) diagnosticado com um sarcoma de tecidos moles em regiáo cervical dorsal, sendo realizada a exérese cirúrgica associada a protocolo quimioterápico metronômico em caráter adjuvante. A combinação terapêutica se mostrou eficaz no controle da doença, garantindo sobrevida importante, na ausência clínica de efeitos colaterais.
\end{abstract}

PALAVRAS-CHAVE: oncologia; neoplasia; histopatologia; aves silvestres; psitacídeos.

\section{INTRODUCTION}

With the new management and nutrition techniques development and the wildlife medicine advancement, an increase in the longevity of these animals has been observed, favoring the greater occurrence of tumor processes (ROBAT; AMMERSBACH; MANS, 2017). In birds, neoplasms involving the integument and the urogenital system are the most common (LEACH, 1992), however there is still a lack of studies in the Brazilian scenario to corroborate such data. In this context, parrots comprise the group of birds in which the greatest neoplasia cases description is observed (FILIPPICH, 2004), with various tumor types reports in blue-fronted amazon (Amazona aestiva), such as lipomas (OLIVEIRA et al., 2006), basal cell carcinomas (TELL, LA; WOODS, L .; MATHEWS, KG, 1997), hemangiosarcoma (MARIETTO-GONÇALVES; GRANDI, 2013), melanomas (FILHO et al., 2017), among others.

Among the integumentary neoplasms, soft tissue sarcomas are highlighted, a group of mesenchymal origin neoplasms that present mostly cutaneous manifestations, and 
similar biological behavior, related to high rates of expansion and local infiltration and low metastatic potential. Among the group components are fibrosarcoma, myxosarcomas, liposarcomas, among others (WITHROW; VAIL; PAGE, 2020).

Surgical excision is widely used in cancer treatment both in birds (CASTRO et al., 2016, 2016) and in cutaneous sarcomas treatment in feline and canine species, being the treatment of choice (WITHROW; VAIL; PAGE, 2020). In some cases, assessing the disease extent and the neoplastic type, adjuvant treatment modalities, such as conventional chemotherapy and metronomic chemotherapy, may be indicated (WITHROW; VAIL; PAGE, 2020). The metronomic modality has greater applicability in these cases, due to its ease administration, facilitating management in these patients. The protocols used derive from veterinary medicine in other species, mainly dogs and cats (WITHROW; VAIL; PAGE, 2020; ZEHNDER; GRAHAM; ANTONISSEN, 2018).

The aim of the present study is to report a case of sarcoma in a blue-fronted amazon (Amazona aestiva) submitted to surgical excision followed by an adjunct metronomic chemotherapy protocol.

\section{CASE REPORT}

At a veterinary clinic in the metropolitan region of São Paulo, a blue-fronted amazon (Amazona aestiva), of unknown gender, approximately 6 years old, weighing $530 \mathrm{~g}$, presenting a dorsal cervical nodule with an evolution of about 3 months. The animal had normal excreta, good body condition, normal food and water intake, and remained alert and responsive at the assessment.

Through the clinical examination, it was found that the increase in volume had a firm, sessile consistency and adhered to the adjacent soft tissues, measuring approximately $6.0 \times 5.0 \mathrm{~cm}$ (Figures $1 \mathrm{~A}$ and $1 \mathrm{~B}$ ). The animal also had bilateral apteria in the wings and neck dorsal region, without growing feathers (sheaths) or self-mutilation signs. At the consultation, a fine needle aspiration puncture (FNAB) was performed for cytological evaluation and requested a cervical region radiography.

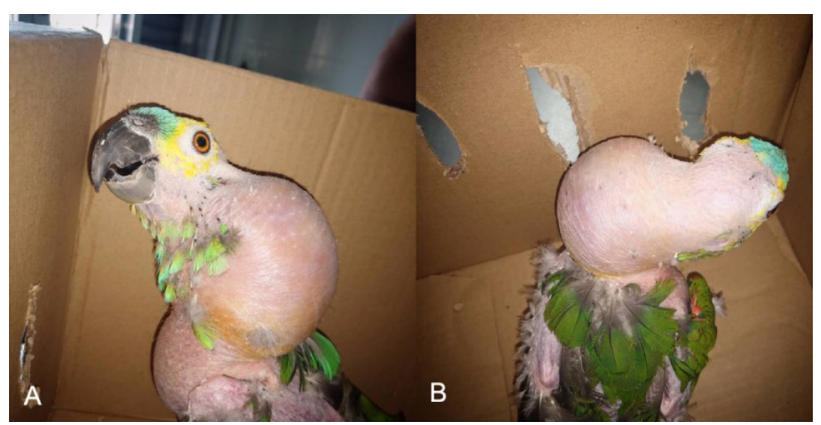

Source: Authors' collection.

Figure 1. Blue-fronted amazon (Amazona aestiva) showing a dorsal cervical nodule, with a marked region of apteria. Lateral view $(A)$ and dorsal view $(B)$.
Initially, the animal was medicated with non-steroidal antiinflammatory drugs, based on meloxicam (Flamavet ${ }^{\oplus} 0.2 \mathrm{mg}$ ), $0.2 \mathrm{mg} / \mathrm{kg}$, each $24 \mathrm{~h}$, for five days.

In the cytological examination, a large amount of blood was observed, making it impossible to analyze the other cell populations morphological characteristics. The radiographic examination was performed in the laterolateral (left decubitus) and ventral-dorsal projections, in order to approach the cervical region and the celomic cavity in single projections. The region that comprised the nodule showed a defined limits area and regular contours, homogeneous aspect, measuring $6.09 \times 6.13 \mathrm{~cm}$ and adjacent to the vertebral bodies, without adherence to them, extending from $\mathrm{C} 1$ to the $\mathrm{C} 7$ cranial epiphysis, without bone changes. No radiographic abnormalities were observed in the coelom cavity.

Five days after the initial treatment, the patient was referred for surgery, with an increase in the nodule of about $10 \%$ in size observed in the first consultation. Prior to surgery, the animal remained alert, responsive, in normal food and water intake. Tramadol hydrochloride was used as preanesthetic medication, intramuscularly. Anesthetic induction was performed using a face mask with isoflurane vaporized in a universal vaporizer, and maintenance was performed using the same gas, offered via an endotracheal tube. The patient was maintained with a cannulated ulnar vein, with administration of lactated ringer's solution, being monitored via vascular doppler and electrocardiogram.

the nodule excision was performed by a skin incision, followed by the peritumoral region divulsion, observing regular contours, in addition to the presence of intense neovascularization

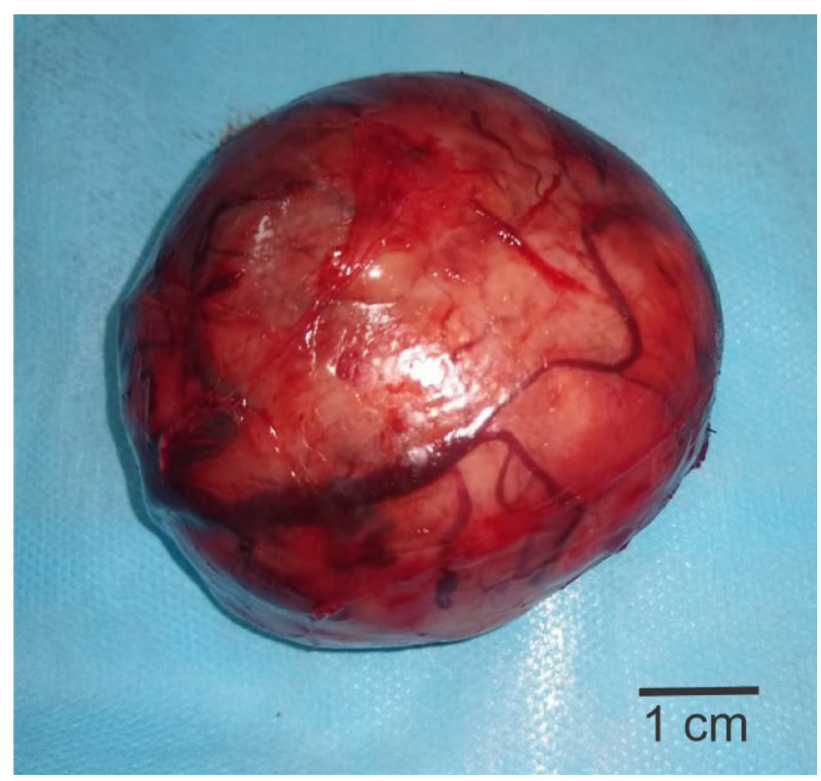

Source: Authors' collection

Figure 2. Cervical nodule after surgical excision, with regular contours, circumscribed and hyperemic appearance with areas of neovascularization. 
in the mass, with no evidence of invasion to adjacent tissues. There were no complications during the procedure with the parameters remaining stable throughout the anesthesia. The animal was discharged with the prescription of enrofloxacin $15 \mathrm{mg} / \mathrm{kg}$, orally, twice a day for 10 days, dipyrone $25 \mathrm{mg} / \mathrm{kg}$, orally, three times a day for 4 days and meloxicam $0.2 \mathrm{mg} / \mathrm{kg}$, orally, once a day for four days.

The removed material was sent for histopathological evaluation, conserved in $10 \%$ formaldehyde, not buffered. Microscopic analysis showed high cellularity, with differentiated mesenchymal cells neoplastic proliferation, occupying the analyzed section entire length. The observed neoplastic cells were arranged in short bundles and storiform arrangement, elongated and with indistinct cell edges, eosinophilic cytoplasm, with ovoid to elongated nuclei with finely dotted chromatin and discretely distinct small nucleoli. Discrete anisocytosis was observed, with a low mitosis figure count (average of one mitosis in ten 400x fields) (Figure 3). The histopathological report indicated a low grade soft tissue sarcoma.

After 15 days of the surgical procedure, the stitches were removed, and a metronomic chemotherapy protocol was started using cyclophosphamide at a dose of $12.5 \mathrm{mg}$ $/ \mathrm{m}^{2}$, orally, once a day associated with piroxicam $0.3 \mathrm{mg}$ $/ \mathrm{kg}$, via oral, once a day, both in continuous use. The animal remained under metronomic treatment for six months, followed by periodic follow-up. Until the present moment, one year after diagnosis and treatment, there have been no local recurrences, the patient maintains normal food and water intake and presenting feathers growth in the previously affected areas.

\section{DISCUSSION}

Sarcomas, as described in this report, are frequent in companion animals (WITHROW; VAIL; PAGE, 2020), but their real incidence is not known in birds, including the blue-fronted amazon. However, several reports illustrate different neoplasms

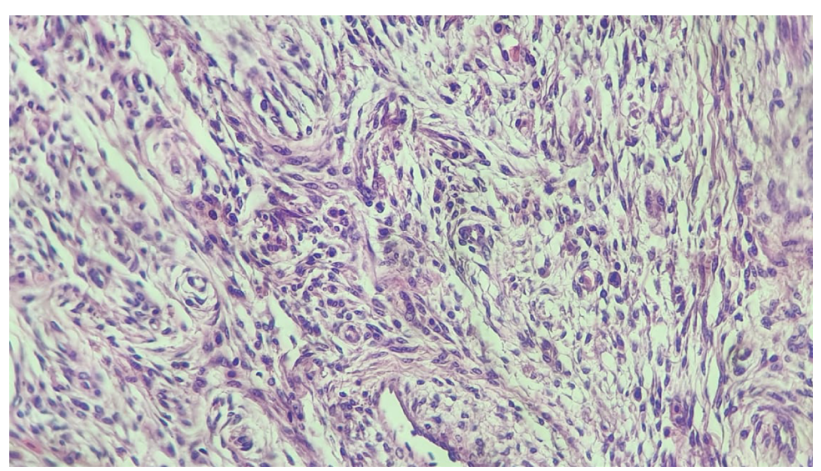

Source: Authors' collection

Figure 3. Mesenchymal neoplastic proliferation, well differentiated, with short bundles and storiform arrangement. 1000x magnification, H\&E coloring. cases within the sarcoma group, affecting species such as hemangiosarcoma (MARIETTO-GONÇALVES; GRANDI, 2013), neurofibrosarcomas (PACHALY et al., 2016), chondrosarcomas (BLUME et al., 2015) and rhabdomyosarcomas (ARAÚJO et al, 2007).

The cytology exam is considered a screening exam, and in the case of sarcomas, the technique may be even less effective due to the low exfoliative character associated with this neoplastic type (WITHROW; VAIL; PAGE, 2020). In the present report, the cytological examination was performed, but with an inconclusive result, with the diagnosis obtained after histopathological evaluation, in accordance with similar reports described in the literature (PACHALY et al, 2016; BLUME et al., 2015; ARAÚJO et al., 2007). Complementary exams, mainly image exams, can assist in oncological diagnosis as well as in making decisions about the therapies used, assessing the invasion degree to adjacent tissues and the presence of local and distant metastasis (WITHROW; VAIL; PAGE, 2020). In the described case, the radiographic examination made it possible to estimate the nodule extent, facilitating surgical planning.

In the present report, surgical excision was used as a therapeutic modality, and it is not possible to consider safety margins due to the affected anatomical region difficulty, close to important structures, such as the right jugular vein, esophagus, right common carotid artery and trachea. Surgical excision is considered the treatment of choice in cases of sarcomas, also in birds (CASTRO et al., 2016) and due to its locally invasive behavior it is recommended to always respect the safety margins, described varying from 2 to $5 \mathrm{~cm}$ (WITHROW; VAIL; PAGE, 2020). There are currently no established safety margins for surgical excision in birds, and in most cases simple surgical excision is used (MARIETTO-GONÇALVES; GRANDI, 2013; PACHALY et al, 2016; BLUME et al., 2015; ARAÚJO et al., 2007) in accordance to the performed.

Adjuvant chemotherapy can be used to treat sarcomas as an attempt to minimize recurrence rates and prolong survival, especially in cases where it is not possible to obtain safety margins. The metronomic modality has been widely studied in companion animals, in protocols using cyclophosphamide and piroxicam (WITHROW; VAIL; PAGE, 2020), as used in the case. However, its use in similar cases is not routinely described (MARIETTO-GONÇALVES; GRANDI, 2013; PACHALY et al, 2016; BLUME et al., 2015; ARAÚJO et al., 2007).

The prognosis for soft tissue sarcomas is considered favorable, in dogs and cats, in cases of low histological grade and when the treatment is correctly used (WITHROW; VAIL; PAGE, 2020). Survival rates in birds are variable, with good responses associated with surgical excision (CASTRO et al., 2016). In the present report, we observed a one-year survival to date, obtained through the association of surgical excision and adjuvant metronomic chemotherapy. 


\section{CONCLUSION}

The surgical excision associated with metronomic chemotherapy with cyclophosphamide and piroxicam proved to be an effective combination, guaranteeing therapeutic success, with at least nine months of recurrence-free survival. However, further studies are needed to prove such efficacy and to accurately assess the possible associated side effects.

\section{REFERENCES}

ARAÚJO et al. Rabdomiossarcoma alveolar em papagaio (Amazona aestiva). Acta Scientiae Veterinariae, v.35, n.l, p.115-117, 2007.

BLUME G. R. et al. Vertebral chondrosarcoma in a blue-fronted parrot (Amazona aestiva). Ciência Rural, v.45, n.3, 2015.

CASTRO, P.F. et al. Prevalence of neoplastic diseases in pet birds referred for surgical procedures. Veterinary Medicine International, v.2016, p.1-7, 2016.

FILHO, O. B. et al. Anterior uveal melanoma in a blue-fronted Amazon parrot (Amazona aestiva) - Case report. Brazilian Journal of Veterinary Medicine, v.38, n.l, p.127-130, 2017.

FILIPPICH, L.J. Tumor control in birds. Seminars in Avian and Exotic Pet Medicine, v.13, n.l, p. 25-43, 2004.

LEACH, M.W. A survey of neoplasia in pet birds. Seminars in Avian and Exotic Pet Medicine, v.l, n.2, p.52-64, 1992.

MARIETTO-GONÇALVES, G.A.; GRANDI, F. Facial Hemangiossarcoma in a Blue-Fronted Amazon Parrot (Amazona aestiva). Acta Veterinaria Brasilica, v. 7, n.l, p. 73-75, 2013.
OLIVEIRA, F. S. et al. Exérese de lipoma em papagaio-verdadeiro (Amazona aestiva). Acta Scientiae Veterinariae, v. 34, п. 2, p. 201-203, 2006.

PACHALY et al. Neurofibrossarcoma em papagaio-verdadeiro (Amazona aestiva) - Relato de caso. Brazilian Journal of Veterinary Medicine, v.38, n. 1, p. 115-119, 2016.

REPETTI, C. S. F; BARROS V. T. M. Metronomicchemotherapy in dogs: a review. Revista Portuguesa de Ciências Veterinárias, v.l10, p.49-53, 2015.

ROBAT, C.S.; AMMERSBACH, M.; MANS, C. Avian Oncology: Diseases, Diagnostics, and Therapeutics. Veterinary Clinics of North America: Exotic Animal Practice, v.20, n.l, p.57-86, 2017.

TELL, L.A.; WOODS, L.; MATHEWS, K.G. Basal cell carcinoma in a blue-fronted amazona parrot (Amazona aestiva). Avian Diseases, v. 4l, n. 3, p.755-759, 1997.

WITHROW, S. J.; VAIL, D. M.; PAGE, R. L. Small Animal Clinical Oncology. 6 ed. St. Louis: Elsevier, 2020. 768 p.

ZEHNDER, A.; GRAHAM, J.; ANTONISSEN, G. Update on Cancer Treatment in Exotics. Veterinary Clinics of North America: Exotic Animal Practice, v.21, n.2, p.465 - 509, 2018. 